\title{
Regional differences of technology modernization in agriculture of Pará State
}

\author{
Mario Miguel Amin Garcia Herreros ${ }^{1}$, Heriberto Wagner Amanajás Pena ${ }^{1 *}$, \\ Allan Klynger da Silva Lobato ${ }^{2}$ and Raimundo Thiago Lima da Silva ${ }^{3}$ \\ ${ }^{1}$ Centro de Ciências Naturais e Tecnologia, Universidade do Estado do Pará, Belém, Brazil. \\ ${ }^{2}$ Núcleo de Pesquisa Vegetal Básica e Aplicada, Universidade Federal Rural da Amazônia, Paragominas, Brazil. \\ 3Centro de Ciências Rurais, Universidade Federal de Santa Maria, Santa Maria, Brazil.
}

Accepted 1 June, 2012

\begin{abstract}
The objective of this study is to identify, through the application of factor analysis and cluster analysis, the spatial organization of the micro hydrographic regions (MRHs) of the State of Pará, as a result of the technology level used in agriculture, the volume of investments, financed credit and by the incorporation of modern means of production. To meet the objectives of the study, information from the Agricultural Census of 2006, published in 2007 by the Brazilian Institute of Geography and Statistics (IBGE) was used. The results indicate that the structural changes occurring within the State's agriculture, during the last two decades have increased considerably in certain MRHs, the regional income by directing most of the production for the export market. However, this led at the same time to a significant reorganization of agrarian space, in other MRHs, where high rates of unemployment and poverty increasing the regional inequalities prevail.
\end{abstract}

Key words: Technological modernization, factor analysis, clusters analysis.

\section{INTRODUCTION}

The investment needed for economic expansion and social development of a region can only be achieved through the accumulation of capital. Their availability makes it possible to move from low to high levels of productivity. Capital formation is therefore of vital importance to ensure the ability to break the "vicious circle of poverty" that, according Nurske (1957), becomes the main obstacle to economic development.

After seven decades, problems linked to insufficient investments still appear in several publications, which are explained in works of Diederen (2003) and Bahiigwa et al. (2005), when explaining why the producer must use technology. Therefore, the modernization of agriculture can reduce poverty. In addition, different methodologies suggests that the innovation is positively related to work level, increase in productivity, market position, access to information, and accumulation of capital.

The new productivity gains for agricultural products supplied by technological advancement were considered as the main driving force for the development of this 
sector, and public agents have promoted technological change through investments in research, infrastructure and institutional support, capable of regulating the market failures. However, the economic power in the study of the interactions between technology, markets, agricultural incomes and public policies involving farmers, reveal that the dimensions of those trends remain determinants, and in essence imperfectly understood (Gardner, 2001).

In this sense, Pastore (1973) also indicates that during stages of economic development, agriculture is a dominant sector in the use of resources and generation of income. Therefore, the development of society is considered to depend fundamentally on the process of modernization of agriculture.

In comparison, the three economies of Latin America (Brazil, Chile and Mexico), present similar problems, because production and productivity increased, however employment and cultivated area reduced within situation of change from traditional to non-traditional products, the amount of family farmers, accompanied by significantly reduced greater concentration of land and social inequality (David et al., 2000).

A large agricultural sector growth does not define its leadership for economic growth, because in poor countries and in development, the proportion linked to agricultural products is very low, compared to the rest of the economy, which already admits that its expansion may not be as good for growth, because there are problems of diverse causes. After fifty years of scientific research on development of agriculture, there are clear positive associations between substantial increase in agricultural productivity and economic growth (Gollin, 2010).

In the perspective region, the dynamics of modernization in agriculture of Pará is in sharp contrast with the concepts and approaches that underscore the importance of technological innovation for economic development that represents a region. In a study about the new standard of Brazilian agriculture, Kageyama et al. (1990) described that the modernization of agriculture means primarily the change in technical basis of agricultural production. It is a change in the technical basis of production that turns the craft production of the peasant-based hoe, in a modern agriculture, intensive, mechanized, and finally, a new way of producing agricultural products.

The incentive for centuries has been given to the extractive economy over the market economy; it was a factor in the process of occupation and use of the geographical area of the State of Pará. The extraction conditioned the region to a position of a typical manufacturer-exporter of raw minerals, animal and plant, reducing its ability to generate the capital needed for the structural transformation of the regional economy.

Other factors were appointed by the analysis of export structure of the State of Pará, in which the image visualized is extractives, reflexing it due to 25 products studied respond for $97.2 \%$ of the total value, composed basically by commodities, if compared with international scenario, and these facts represent loss of business opportunities or market exceeding $80 \%$, being large portion of this amount transferred to other countries that maintain business relationship with Pará State (Pena et al., 2008).

Technological advances have accelerated the food production and the consolidation of agribusiness as the main income generating sector in the national economy. Similarly, the process of modernization and expansion of the horizontal and vertical growth of agriculture in other states of the federation has been a key factor for maximizing the profitability of the agricultural sector. This process seems to have been very well incorporated through the economy of the State of Pará. While maintaining a close relationship between public policies with the old economic model of exploitation, these regional inequalities in social and economic terms have become substantial. The current growth of the agriculture of Pará presents a spatial differentiation that comes to reinforce a trend that began in earlier decades, when the projects come to occupy well-defined regional areas making it clear not only in the form of occupation, but as well as the influence of the implementation of large projects responsible for micro-regional agricultural focus of economic development of the state.

The importance and contribution to the modernization of agriculture for capital formation is expressed by Johnston and Mellor (1972) considering five principles: (i) The increase in agricultural production and agricultural productivity contribute substantially to meet the demand for food; the lack of an expansion in the food supply can seriously damage the region's economic growth; (ii) the exportation of agricultural surpluses is also one of the fastest ways to raise incomes and accelerate regional economic development; (iii) once you overcome the first stages of development, the agricultural sector passes to supply the processing industry and other sectors with a large contingent of skilled labor; (iv) agriculture has an important role in contributing to the formation of capital (savings), and capital accumulation is considered as a factor of vital importance to the expansion of other sectors of the economy; $(v)$ it has been established as a source of food production and capital, that the agricultural sector becomes a major center of encouraging the expansion of the industrial sector.

By have remained in merely extractive activities: plants, minerals and animals, it was not possible to develop the purchasing power of the state population. It avoided, of course, the generation and consolidation of sufficiently large market to stimulate investment. Part of the stagnation of the economy of the State of Para may be explained also by the size of its market.

Regarding the importance of developing a market economy in which the interaction of the forces of supply and demand are factors that help in determining the size 
of the market and at the same time streamline their behavior, Nurske (1957) is very clear to state that:

... the common observation shows that, in the poorest countries, the use of equipment capital in the production of goods and services for production is constrained by market size, lack of purchasing power... In the economy of exchanges in the real world, is not difficult to illustrate the way in which the small market size of a country can discourage or even prevent the profitable application of modern capital equipment for any particular individual entrepreneur or industry ... The limited domestic market size in a low-income country may thus constitute an obstacle to application of capital by any private company. In this sense, the smallness of the internal market is usually an obstacle to its development".

The regional characteristics have shaped the spatial concentration of investment and capital formation that contributes most to increasing regional imbalances than to improve the economic dimension of most agricultural establishments. This study aims to identify, through the application of factorial analysis and cluster analysis, the spatial organization of micro regions of the State of Pará, the resulting level of technology used in agriculture, the volume of investment, credit financed and the incorporation of modern means of production.

\section{MATERIALS AND METHODS}

\section{Source of data}

To answer the objectives of the study, it was necessary to choose, first, the level of aggregation of information. This phase is very important in studies of regional character in which one seeks to identify the dynamics and the relationship between a certain group of variables and a selected group of locations. For this work, we used the information presented in the 2006 Agricultural Census of the Brazilian Institute of Geography and Statistics - IBGE. Three options were available: the level of municipalities, micro and meso regions. Given the peculiar characteristics of the agricultural economy of the State of Pará, it was deemed appropriate to choose the statistics presented in micro hydrographic regions (MRHs), since the level of aggregation used by the IBGE allows identifying regional inequality without compromising local specificities. The Agricultural Census of IBGE of 2006 identifies $22 \mathrm{MRHs}$ Homogeneous in Para State, including 138 municipalities out of 143. The difference is explained by the lack of regional information on some of the municipalities visited.

\section{Selection of variables}

Given the marked regional differences in Brazilian agriculture regarding the use of productive factors and the incorporation of technological innovations, it was necessary to select variables which, although different from those incorporated in the studies of Hoffmann (1992), Figueiredo and Hoffmann (1998), as well as Souza and Khan (2001), aiming to characterize the level of technological modernization between different regions, allowing to identify, given the spatial location of administrative and economic activities of farmers, the specific process of technological specialization of each micro-region.

The characterization of the regional process of technological incorporation of farmers of Para was obtained by selecting four groups of indicative variables of the intensity of capital used in the modernization of regional agriculture. The variables selected are related to expenses in productive activities, with the value of production of permanent and temporary crops, and quarrying, with funding and, finally, with investments. Given the importance that livestock has reached in recent years in the State of Pará, it was included as a variable of analysis, the pasture of planted area. The variables used as indicators of the degree of technological incorporation in MRHs selected are listed as follows:

$\mathrm{X} 1=$ Expenses with payroll,

$\mathrm{X} 2$ = Expenses with fertilizers,

$\mathrm{X} 3=$ Expenses with seeds,

X4 $=$ Expenses with pesticides,

$\mathrm{X} 5=$ Expenses with production transportation,

$\mathrm{X} 6=$ Expense with interest / bank,

$\mathrm{X} 7=$ Expenses with taxes,

$\mathrm{X} 8=$ Expenses with fuel / lubricants,

X9 = Expenses with energy,

$\mathrm{X} 10=$ Value of large livestock,

$\mathrm{X} 11=$ Value of production of permanent culture

$\mathrm{X} 12$ = Value of production of temporary culture,

$\mathrm{X} 13=$ Value of extractive production,

$\mathrm{X} 14$ = Financing for cost,

$\mathrm{X} 15=$ Financing for investment,

X16 = Financing for commercialization,

$\mathrm{X} 17=$ Investments in land,

$\mathrm{X} 18=$ Investment in improvements,

$\mathrm{X} 19=$ Permanent investment in culture,

$\mathrm{X} 20$ = Investment in machinery,

$\mathrm{X} 21=$ Investment in vehicles,

X22 = Planted area pasture.

It can be inferred that, given the rational behavior of producers, each of the 22 selected variables is sufficiently a representative of the technical relations that determine the application of capital and the strategies adopted in the selection of agricultural practices that, within the limitations and specificities, are considered the most profitable.

\section{Method of analysis}

The availability of a large number of statistical methods, as well as several software programs that enable the rapid implementation, has helped to gain a high degree of speed in identifying georeferenced regional of socioeconomic differences. In this study, as it will be used, initially, the multivariate analysis is known as factor analysis and cluster analysis. Subsequently, the results will be georeferenced using the technique of the Geographic Information System (GIS), thus allowing better visualization of regional differences in the use of technological factors.

\section{Factorial analysis}

Factor analysis can identify the pattern of dependence or interdependence between a certain groups of variables. This relation is given initially by the degree of correlation between variables, passing later to be grouped on factors that highlight the "real relationship" between the structural variables (Hartman, 1976; Boyd et al., 1981; Mardia et al., 1980; Hair et al., 1998).

Otherwise, the correlation structure used in statistical technique involves how the database search will respond to the research problem in general, provoking reduction in number of variables, 
without causing loss of significance (Rodrigues and Paulo, 2009). The application of factorial analysis requires several steps. The first is related to determining the level of association between variables by calculating the correlation matrix. The degree of association between the variables determines whether it is feasible to use factor analysis. In the second step, it is necessary to determine the number of factors that must be estimated.

There are several alternatives depending on the software used. In this paper, we used the method described by Boyd et al. (1981) and Aaker and Day (1983), which is based on the criterion of Kaiser. The criterion states that those factors that have eigenvalues with a value greater than 1 , guide the decision to advise or advice regarding the replacement of the variables set by the factors observed (Pison et al., 2003; Jin, 2011). This process can be validated through the generation of the graph called the Scree Plot, in which all eigenvalues are presented.

Once selected, the number of factors, it passes to extract the most significant factors that represent the data. When performed this step, it is necessary to apply the technique of rotation of factors to make them statistically more usable. The option used in this study was to Varimax normalize. Normalizing the data is necessary, since some of the variables used in the research are expressed in different units. Estimated factors and factor loadings (factor loadings) indicate the correlation of variables within each factor, thus it becomes necessary to estimate the factor scores (factor scores) that will be used later in the cluster analysis.

\section{Cluster analysis}

Cluster analysis is widely used to identify the degree of interdependence between numbers of variables. The technique allows identifying and grouping those variables that have a strong similarity to its basic structure. Significant differences in the structural composition of the cluster to cluster also can be identified (Boyd et al., 1981; Mardia et al., 1980; Hair et al., 1998).

The identification of clusters can be accomplished through various algorithms. The most commonly used in the literature of multivariate analysis are the nodal linkage procedures and nodal procedures. The first alternative has the simple, complete and average linkage. The second algorithm, hardly used because of its complexity analysis, refers to the choice of a cluster object that will serve as the basis for the identification of other clusters (Churchill Jr., 1982). In this study, we used the complete linkage method, viewed as a hierarchical clustering technique, which identifies, through the dendogram, regional differences in the use of technological factors. A more detailed mathematical description of the application of methods of factorial analysis and cluster can be found in the writings of Hartman (1976), Mardia et al. (1980) and Hair et al. (1998).

\section{RESULTS AND DISCUSSION}

\section{Identification of technological modernization}

As a first step in the application of factor analysis, it was estimated in the correlation matrix. It can be seen in Table 1, a strong correlation between most variables. Only four variables, X4 (cost of pesticides), X9 (energy costs) and X13 (value of extraction production) had very low correlations with other variables.

The result is quite surprising. The low correlation shown between expenditure on pesticides and other variables, especially with temporary and permanent crops, crops, occupy a large part of the economy in Pará in the area of mineral extraction, animal or plant character. The low use of pesticides is related also to the kind of climate that exists in the Amazon region. Likewise, extraction and production are basically for family meals and with a much localized trade, the value of extractive production does not present a very significant contribution to overall economic growth of the state.

The lack of energy in cities farther away from the capital, Belém, is a serious problem, passing it to influence negatively the productive capacity and slow the process of incorporating the most modern techniques in agriculture in the state. The funding generally appears as the main inducer of the modernization process of agriculture in Para. Permanent crops depend significantly on the cost of financing, investment and trade. The agricultural credit, especially the Institutional Fund for Financing the North (FNO), plays a very important social and economic development by financing large part of agricultural projects implemented in the Amazon region. Amazon shows how the allocation of resources to productive sectors was essential for the generation of regional income and employment (Amin, 2002; Santana, 2002).

The costs are strongly correlated with most agricultural activities. It indicates that producers are reinvesting part of the capital raised in machinery, improvements, livestock, seed, pasture area, fertilizers and, especially, for payment of the financing arranged.

\section{Determination of groups of factors}

After the implementation of statistical tests and verification that the correlation matrix was not an identity, eigenvalues were estimated to help in identifying a number of factors that can be extracted from the variables used. The criterion of extraction is somewhat arbitrary, but modern statistical algorithms already allow obtaining preliminary information that facilitates the selection of the final number of factors. To answer the objectives of the study, three factors were selected showing eigenvalues of 7.73 for $\mathrm{F} 1,5.36$ for $\mathrm{F} 2$ and 1.84 for F3. The first factor explains $35.16 \%$ of the total variance of 22 variables, the second factor explains $24.38 \%$ and the third factor explains $8.38 \%$ of total variance. It means that three factors explain $68 \%$ of the total variance.

From this information, the rotation was carried out by the VARIMAX method to obtain the normalized factorial loadings (factors loadings) that indicates a correlation between the respective variables and factors, representing the most important information of the factor analysis. The normalization or standardization of variables is of great importance, given that the main objective of the study is to identify, through the application of cluster analysis, the spatial distribution of 
Table 1. Correlation matrix of selected variables.

\begin{tabular}{|c|c|c|c|c|c|c|c|c|c|c|c|c|c|c|c|c|c|c|c|c|c|c|}
\hline & $\mathrm{X} 1$ & $\mathrm{X} 2$ & $\mathrm{X} 3$ & $\mathrm{X} 4$ & X5 & X6 & $\mathrm{X} 7$ & $\mathrm{X} 8$ & $\mathbf{X 9}$ & $\mathrm{X} 10$ & $\mathrm{X} 11$ & $\mathrm{X} 12$ & $\mathrm{X} 13$ & $\mathrm{X} 14$ & $\mathrm{X} 15$ & $\mathrm{X} 16$ & $\mathrm{X} 17$ & $\mathrm{X} 18$ & $\mathrm{X} 19$ & $\mathrm{X} 20$ & $\mathrm{X} 21$ & $\times 22$ \\
\hline $\mathrm{X} 1$ & 1.00 & & & & & & & & & & & & & & & & & & & & & \\
\hline$X 2$ & 0.59 & 1.00 & & & & & & & & & & & & & & & & & & & & \\
\hline X3 & 0.52 & -0.06 & 1.00 & & & & & & & & & & & & & & & & & & & \\
\hline$X 4$ & 0.12 & 0.19 & 0.41 & 1.00 & & & & & & & & & & & & & & & & & & \\
\hline$X 5$ & 0.15 & 0.50 & -0.45 & -0.15 & 1.00 & & & & & & & & & & & & & & & & & \\
\hline X6 & 0.78 & 0.50 & 0.31 & 0.08 & 0.15 & 1.00 & & & & & & & & & & & & & & & & \\
\hline $\mathrm{X} 7$ & 0.75 & 0.44 & 0.37 & 0.04 & -0.18 & 0.56 & 1.00 & & & & & & & & & & & & & & & \\
\hline$X 8$ & 0.63 & 0.13 & 0.44 & 0.08 & 0.04 & 0.55 & 0.38 & 1.00 & & & & & & & & & & & & & & \\
\hline X9 & 0.23 & 0.37 & -0.18 & -0.10 & 0.08 & 0.00 & 0.17 & -0.09 & 1.00 & & & & & & & & & & & & & \\
\hline $\mathrm{X} 10$ & 0.53 & -0.29 & 0.79 & 0.07 & -0.10 & 0.37 & 0.35 & 0.58 & 0.00 & 1.00 & & & & & & & & & & & & \\
\hline $\mathrm{X} 11$ & 0.52 & 0.67 & -0.12 & -0.09 & 0.07 & 0.40 & 0.27 & 0.39 & 0.15 & -0.12 & 1.00 & & & & & & & & & & & \\
\hline $\mathrm{X} 12$ & 0.39 & 0.49 & -0.12 & -0.03 & -0.09 & 0.23 & 0.13 & 0.44 & 0.15 & -0.04 & 0.75 & 1.00 & & & & & & & & & & \\
\hline $\mathrm{X} 13$ & -0.19 & 0.00 & -0.28 & 0.013 & -0.13 & -0.06 & -0.15 & 0.24 & -0.20 & -0.37 & 0.05 & 0.00 & 1.00 & & & & & & & & & \\
\hline $\mathrm{X} 14$ & 0.76 & 0.69 & 0.10 & 0.01 & 0.01 & 0.82 & 0.49 & 0.45 & 0.05 & 0.09 & 0.56 & 0.38 & 0.04 & 1.00 & & & & & & & & \\
\hline X15 & 0.50 & 0.31 & 0.18 & 0.01 & 0.01 & 0.27 & 0.60 & 0.38 & 0.10 & 0.21 & 0.52 & 0.36 & -0.21 & 0.27 & 1.00 & & & & & & & \\
\hline $\mathrm{X} 16$ & 0.65 & 0.73 & -0.01 & 0.02 & 0.02 & 0.77 & 0.47 & 0.29 & 0.00 & -0.11 & 0.56 & 0.28 & 0.15 & 0.94 & 0.26 & 1.00 & & & & & & \\
\hline $\mathrm{X} 17$ & 0.26 & -0.27 & 0.45 & -0.07 & -0.07 & 0.39 & 0.24 & 0.29 & -0.17 & 0.57 & -0.24 & -0.15 & -0.30 & -0.02 & 0.18 & -0.09 & 1.00 & & & & & \\
\hline $\mathrm{X} 18$ & 0.57 & 0.16 & 0.42 & 0.07 & 0.07 & 0.35 & 0.77 & 0.40 & 0.09 & 0.49 & 0.14 & 0.20 & -0.27 & 0.23 & 0.79 & 0.14 & 0.42 & 1.00 & & & & \\
\hline $\mathrm{X} 19$ & 0.52 & 0.65 & -0.07 & -0.07 & -0.07 & 0.45 & 0.08 & 0.33 & 0.14 & -0.05 & 0.86 & 0.68 & -0.08 & 0.64 & 0.34 & 0.57 & -0.14 & 0.01 & 1.00 & & & \\
\hline X20 & 0.81 & 0.65 & 0.24 & 0.12 & 0.12 & 0.91 & 0.60 & 0.48 & -0.05 & 0.18 & 0.52 & 0.30 & 0.02 & 0.93 & 0.36 & 0.93 & 0.17 & 0.34 & 0.54 & 1.00 & & \\
\hline X21 & 0.55 & -0.12 & 0.63 & 0.00 & 0.00 & 0.39 & 0.52 & 0.57 & -0.12 & 0.75 & -0.08 & 0.01 & -0.24 & 0.17 & 0.24 & 0.01 & 0.69 & 0.57 & -0.01 & 0.29 & 1.00 & \\
\hline $\mathrm{X} 22$ & 0.51 & -0.29 & 0.83 & 0.01 & 0.01 & 0.37 & 0.39 & 0.53 & -0.22 & 0.91 & -0.16 & 0.09 & -0.31 & 0.06 & 0.21 & -0.09 & 0.75 & 0.51 & -0.08 & 0.22 & 0.85 & 1.00 \\
\hline
\end{tabular}

the technological modernization of agriculture in the State of Pará, in 22 selected MRHs.

Table 2 presents the estimated factorial loadings after orthogonal rotation. The analysis is based on values greater than 0.50 , in order to identify the extent to which technological changes in agriculture have been incorporated into national regional level. The estimated communalities indicate that the variables selected have their variability very well captured by the three selected factors.

Factor 1 is positively related to the indicators
$\mathrm{X} 1, \mathrm{X} 2, \mathrm{X} 6, \mathrm{X} 11, \mathrm{X} 14, \mathrm{X} 16, \mathrm{X} 19$ and $\mathrm{X} 20$ which represent, in its entirety, the decisions taken by farmers in relation to expenditure, investments and financing in processes. This factor therefore represents all the "financial activities".

The high values of X14 (0.94) and X16 (0.96) indicate that the state's agricultural production depends significantly to the cost of financing and marketing of production. Given the poor conditions of road infrastructure in the state, farmers need to make heavy investments in the purchase or lease of means of transport to the flow of production. This is especially evident in those municipalities located near the Transamazônica highway. Similarly, credit is a key role in encouraging and strengthening the agricultural economy of the state.

In Factor 2, on the other hand, all those activities related to the livestock industry are identified. The factor is positively related to the indicators $X 1, X 3, X 7, X 8, X 10, X 17, X 18, X 21$ and $X 22$. The high values of $X 10(0.88)$ and $X 22$ (0.91) reflect those in which $\mathrm{MRH}$ s predominate the beef cattle industry and milk as the main 
Table 2. Factor loadings and commonalities.

\begin{tabular}{lcccc}
\hline \multirow{2}{*}{ Indicators } & \multicolumn{2}{c}{ Factor } & \multirow{2}{*}{ Communal } \\
\cline { 2 - 4 } X1 - Wages exp. & $\mathbf{1}$ & $\mathbf{2}$ & $\mathbf{3}$ & 0.992 \\
X2 - Fertilizers exp. & 0.73 & 0.57 & 0.25 & 0.990 \\
X3 - Seeds exp. & 0.72 & -0.17 & 0.45 & 0.971 \\
X4 - Pesticides exp. & 0.15 & 0.76 & -0.31 & 0.638 \\
X5 - Exp. trans. prod. & 0.15 & 0.07 & -0.21 & 0.997 \\
X6 - Interest / bank exp. & 0.30 & -0.39 & 0.68 & 0.983 \\
X7 - Taxes exp. & 0.86 & 0.34 & -0.05 & 0.886 \\
X8 - Fuel / lubric. exp. & 0.49 & 0.57 & 0.15 & 0.924 \\
X9 - Energy exp. & 0.44 & 0.53 & 0.22 & 0.851 \\
X10 - Value of large livestock & -0.05 & -0.01 & 0.49 & 0.996 \\
X11 - Perm. value & 0.03 & 0.89 & -0.14 & 0,866 \\
X12 - Temp. value & 0.55 & -0.05 & 0.72 & 0.804 \\
X13 - Extra. value & 0.29 & 0.03 & 0.81 & 0.891 \\
X14 - Fin. cost & 0.16 & -0.44 & -0.09 & 0.992 \\
X15 - Fin. invest. & 0.95 & 0.05 & 0.13 & 0.998 \\
X16 - Fin. comer. & 0.21 & 0.49 & 0.54 & 0.997 \\
X17 - Inv. in land & 0.96 & -0.11 & 0.06 & 0.876 \\
X18 - Inv. in improvements & 0.00 & 0.71 & -0.28 & 0.890 \\
X19 - Inv. in perm. culture & 0.16 & 0.76 & 0.28 & 0.995 \\
X20 - Inv. in machines & 0.58 & -0.06 & 0.59 & 0.997 \\
X21 - Inv. in vehicles & 0.96 & 0.20 & 0.02 & 0.990 \\
X22 - Pasture planted area & 0.14 & 0.85 & -0.13 & 0.982 \\
\hline
\end{tabular}

economic activity. This factor is basically the "farming activity." Factor 3 contrasts with the other two factors. Here, the focus indicators related to the production of permanent crops (X11) and temporary crops (X12), financing for investment (X15), investment in permanent crops (X19) and transportation costs of production (X5). Again, it is evident that the importance of the cost of shipping into the productive matrix represents the State of Pará. This factor reflects the MRHs, where agriculture is the main economic activity. This factor therefore represents the "agricultural activity".

\section{Determination of technological dynamics of micro regions}

As a complementary result to the identification of factors and factorial loadings, it is possible to estimate the factor scores. The scores can be used to identify the dynamics of technological incorporation in each of the selected MRHs, as well as to verify, through cluster analysis, the spatial grouping MRHs according to their productive and technological characteristics. Table 3 presents the results identifying the level of technological incorporation in 22 MRHs analyzed. Building on the analysis of the 22 indicators shown earlier, are highlighted in bold, those $\mathrm{MRHs}$ that have a more advanced technological standard. The results show strong regional disparities in the level of technological modernization of agriculture in the State of Pará. It is observed not only in a well-defined stratification of productive processes, but the low technological level of agriculture that still exists in most $\mathrm{MRH}$ s state.

The micro region of Tomé-Açu presents the highest level of technology due to the significant use of intensive, the capital / labor ratio. The micro region incorporated, from the arrival of Japanese farmers in the 50's, modernizing agricultural practices which have contributed to this region, at present is responsible for a significant portion of the state production of cocoa, black pepper and kingdom tropical fruits. The production orientation of regional products, mostly targeted for the export market, served to ensure a structural change in the growth of agriculture induced by the implementation of modern technologies.

It is worth mentioning also that the process of technological modernization of the micro region of TomeAçu was highly benefited by the location in relation to its proximity to the main ports of export, as well as the available infrastructure. The MRHs of Redenção, Paragominas, São Felix do Xingu, Parauapebas, Conceição do Araguaia and Maraba have developed an economy oriented toward specialization in livestock. These MRHs respond for about $65 \%$ of the effective cattle in the state of Pará estimated in the year of 2000 in 10.2 million heads (IBGE, 2008). In another group, we 
Table 3. Composition of factor scores.

\begin{tabular}{lccc}
\hline \multirow{2}{*}{ Micro regions } & \multicolumn{3}{c}{ Factor } \\
\cline { 2 - 4 } & $\mathbf{1}$ & $\mathbf{2}$ & $\mathbf{3}$ \\
\hline Almeirim & 0.058071 & -0.77443 & -1.40348 \\
Altamira & 0.092584 & 0.97213 & 0.96400 \\
Arari & -0.798371 & -0.56678 & 0.08455 \\
Belém & -0.265567 & -0.76541 & -0.27299 \\
Bragantina & -0.128431 & 0.93009 & 2.69777 \\
Conceição do Araguaia & -0.058509 & 1.80241 & -0.62966 \\
Cametá & -0.312431 & -1.00145 & 0.33003 \\
Castanhal & -0.012178 & -0.66645 & 0.87475 \\
Furo de Breves & -0.159793 & -1.32652 & -0.50526 \\
Guamá & 0.058034 & -0.12642 & 2.29103 \\
Itaituba & -0.512613 & -0.45834 & -0.29093 \\
Marabá & -0.346820 & 0.37682 & -0.69764 \\
Óbidos & -0.537355 & -0.70472 & -0.27265 \\
Paragominas & -0.055366 & 1.23860 & -0.37433 \\
Parauapebas & -0.187892 & 0.72893 & -0.50797 \\
Portel & -0.521210 & -1.05315 & -0.31951 \\
Redenção & 0.454242 & 2.19872 & -0.87229 \\
Salgado & -0.365600 & -0.98510 & -0.22399 \\
Santarém & -0.104096 & -0.12307 & 0.85066 \\
São Felix do Xingu & -0.194987 & 0.93994 & -0.91422 \\
Tomé-Açu & 4.311826 & -0.69396 & -0.15508 \\
Tucuruí & -0.413540 & 0.05815 & -0.65281 \\
\hline & & & \\
\hline & & & \\
& & &
\end{tabular}

highlighted the MRHs of Bragantina and Guamá with an oriented agriculture to supply the regional market. The return of capital from agriculture contributes significantly to these MRHs, the most important centers of employment and income generation in the State. As in the case of micro region of Tome-Açu, these MRHs have also been privileged with a great infrastructure. Micro regions as Altamira, Cametá, Santarém and Castanhal occupy an intermediate position regarding the level of technology embedded in their productive activities. The micro region of Tucuruí has taken, in recent years, an important position in the agricultural state, accounting today for $3.5 \%$ and the actual state of the beef cattle (IBGE, 2008). The micro regions Almeirim, Arari, Belém, Furo de Breves, Itaituba, Óbidos, Portel and Salgado present no score for identifying the development of farming practices that are being incorporated into technological modernization. Low scores represent the existence of a low technological level due to the strong presence of agriculture and quarrying.

\section{Cluster analysis}

In possession of scores of factors, it is possible to perform additional statistical analysis. In particular, the resulting information can be exploited to define groups that characterize cases (MRHs) with a certain degree of homogeneity. Using the three estimated factors scores, the $22 \mathrm{MRHs}$ were hierarchically grouped into six clusters.

According to the results of dendrogram (Figure 1), there are well-defined groups according to the level and technological use in agriculture. The first cluster is formed by micro region of Tome-Açu. The importance of this micro region in the state economy is evident from the rank observed in the dendogram estimated. The second cluster, where commercial agriculture is the basis of the regional economy, is composed of five MRHs: Guama, Bragantina, Santarem, Conceicao de Araguaia and Altamira. These are cluster grouped areas where capital flows and the incorporation of technology have been instrumental in the development and structural transformation of agriculture in the state.

The third cluster is formed by micro region of Redenção participating at the time, with 1.9 million head of sheep and $18.63 \%$ effective in the State of Pará (2008). The pattern of technological factors adopted from 1995, has converted this area into a major beef-producing center of the North. Completing this cluster were the MRHs Paragominas and Cameta. The fourth cluster is formed by MRHs of Sao Felix do Xingu, Paraupebas Tucuruí and Maraba. The MRHs of this group and the previous one forms the largest producer and beef cattle in the state. The significant increase in exports of beef from Brazil has been a conditioning factor for the adoption of advanced technology initiatives that are transforming the pattern of development in this region.

The MRHs of Salgado, Portel, Belém, Castanhal, Óbidos, Itaituba and Arari form the fifth cluster. This group of $\mathrm{MRHs}$ is characterized by an agriculture that coexist a low technological level of production and a regional economy geared basically for mining activities. The sixth cluster is formed by micro-Almeirim. The segmentation of this region in a well isolated cluster reflects very clearly the inequality in the use of regional factors and technological modernization. Characterized by a regional economy and quarrying, their contribution to the state's economy is almost marginal. The six clusters identified by the 22 indicators used and agricultural modernization, allow three basic groupings of economic activity, showing the regional potential, to be formed: agriculture (Clusters 1 and 2), livestock (Clusters 3 and 4) and extraction (Clusters 5 and 6).

The significant heterogeneity in the process of modernization of agriculture can be explained also by how the integration of micro-regions, given by the Euclidean distances (similarity coefficient), is performed (Figure 1). Regional differences can be characterized in terms of the information used and the explanatory power of each factor. The micro-regions, for example, where agriculture is predominant extraction, have been grouped close to the Euclidean distances of 1, showing therefore a relatively lower agriculture in the level of modernization and 


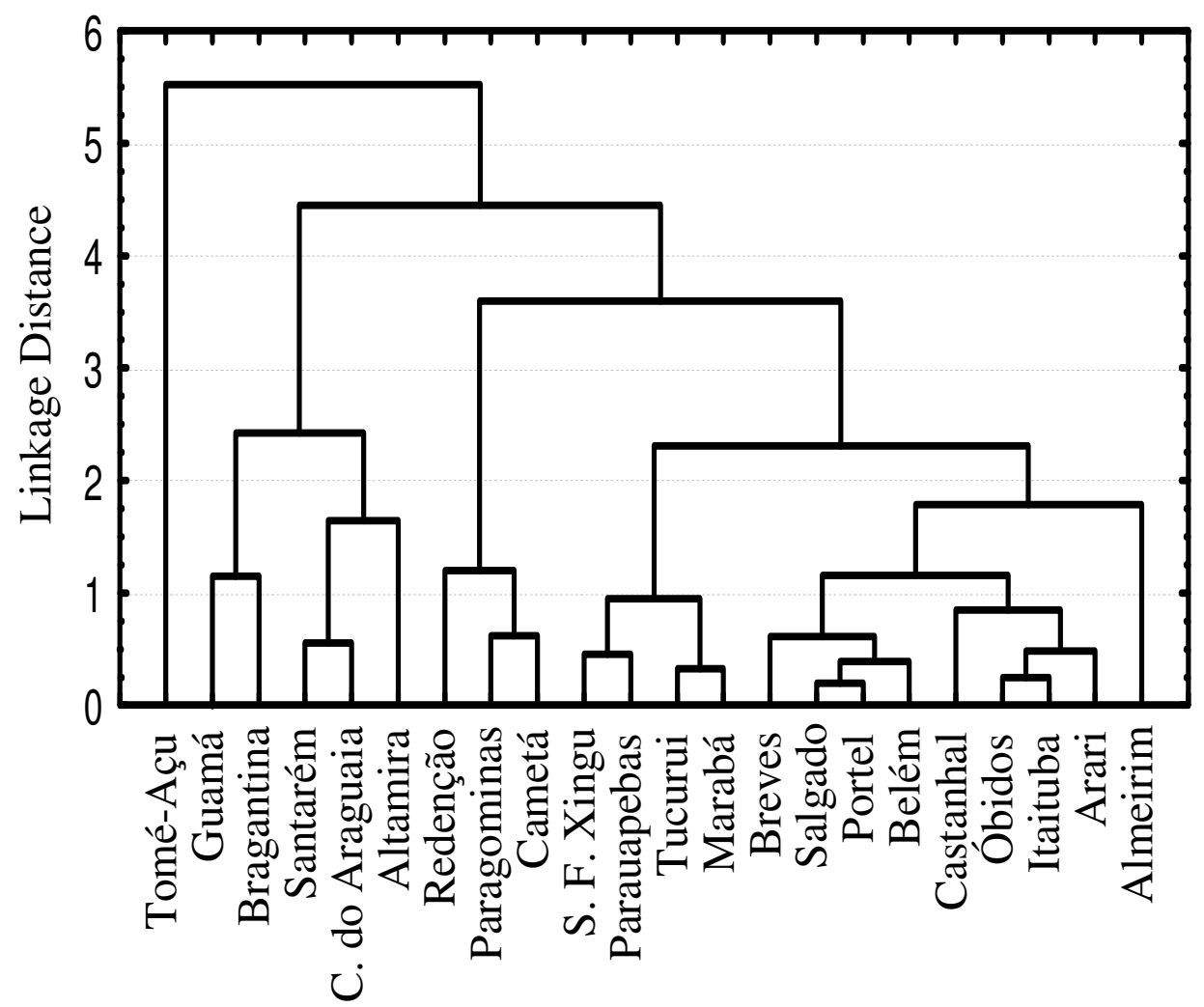

Figure 1. Dendrogram for the clustering of the State of Pará MRHs.

technological expertise. This cluster is integrated into the group formed by the micro-regions of Sao Felix do Xingu, Paraupebas Tucuruí and Maraba, where ranching is the main activity, at a distance of 2.25 .

The micro-regions of Redenção, Paragominas and Cameta, on the other hand, where ranching is the predominant basis of the regional economy, integrate the general system, at a distance of 3.75. Following by importance are the micro regions of Guama, Bragantina, Santarem, Conceição de Araguaia and Altamira where commercial agriculture is dominant and most representative industrial. The integration of these micro regions is made at a distance of 4.25 .

The micro region of Tome-Açu is the last to integrate the system due to its large Euclidean distance of 5.5, emphasizing thus the importance that the implementation of advanced standards of technology and modernization of the capital / labor ratio in agriculture has regional level. By georeferencing the results presented earlier, it is possible to identify spatially regional inequalities, and the use of modern technologies in agriculture and regional development. Figure 2 shows the regional differences in the level of use of technological factors and the modernization of agriculture in the State of Pará.

At first glance, it emphasizes the heterogeneity of an agriculture state. This is reflected as an indication of the pattern of technological and productive economic activities in MRHs.

The observed clusters follow a geographical contiguity, indicating a regionally well defined, in relation to the technological modernization of agriculture in the state. In the northern region of the state (Clusters 5 and 6 ), the extractive agriculture, whether by animal or plant, is the main source of employment and income. The remarkable lack of energy, transport infrastructure and services in general, has served to that in terms of technology investments, this part of the state remains on the fringes of economic development.

Those MRHs in which the predominate agriculture has a more advanced technological level are located in the center and northeastern parts of the state (Clusters 1 and 2). This region is characterized by a level of specialization and diversification of productive processes reasonably modern making it the leading supplier of food both for regional consumption and for export.

In the southeast of the state (Clusters 3 and 4), it is a distinguished set of MRHs characterized by a high technological standard and by a significant increase in agriculture, which became the main activity of regional development. The proximity of the States of Mato Grosso, Goias and Tocantins, major producers of beef cattle have served to create a favorable environment for 


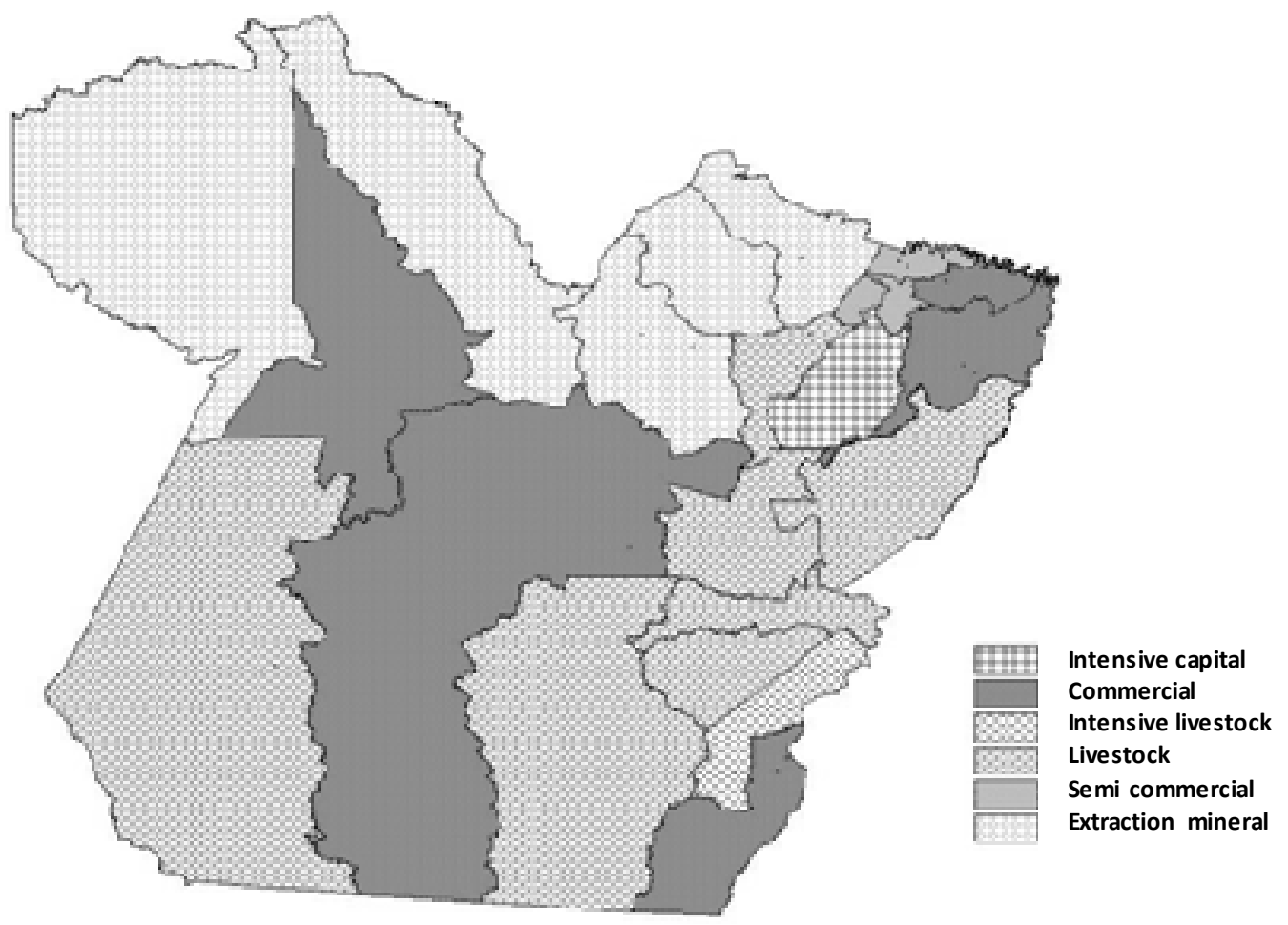

Figure 2. Regionalization of the technological modernization of agriculture in the State of Pará.

the installation of refrigerators, with the positive balance growth of the herd during the past ten years. It is important to mention that these last two groups of MRHs, unlike the first, are very well served by an extensive infrastructure of transport, energy and services.

\section{Conclusions}

The model of agricultural growth in the state of Para, centered mostly in the extractive exploitation of natural resources, shows very significant differences regarding the spatial level of technology used in productive activities. In addition, six clusters identified by statistical methods of analysis of factor and cluster find a spatial organization resulting from the various historical processes of land occupation in the state. The inter-regional differences are determined in three economic activities: commercial agriculture, livestock, farming and mining. The technological modernization of agriculture in the State of Para provides to the set of MRHs in question a well defined spatial segmentation. The process occurred very differently by incorporating spaces in which the tone of the investment, financing and technical management in agriculture was given in different business manners. Therefore, the structural changes occurring within the state agriculture during the last two decades, increases dramatically at certain MRHs, the regional income by guiding most of the production for the export market. But, it leads at the same time, to a significant reorganization of the agricultural space in other MRHs, where prevailing high rates of poverty and unemployment, deepening regional inequalities.

\section{REFERENCES}

Aaker DA, Day GS (1983). Marketing research. New York: Wiley \& Sons.

Amin MM (2002). Situação da pecuária na Região Norte: tendências e perspectivas. IN: O Fundo Constitucional de Financiamento do Norte e o Desenvolvimento da Amazônia, Santana AC de. Belém: M\&S Editora.

Bahiigwa G, Rigby D, Woodhouse P (2005). Right Target, Wrong Mechanism? Agricultural Modernization and Poverty Reduction. World Dev. 33:481-496.

Boyd HW, Westfall R, Stasch SF (1981). Marketing research: texts and cases. Ontario: Irwin Inc.

Churchill GA (1982). Marketing research: Methodological foundations. Illinois: The Dryden Press.

David B, Dirven M, Vogelgesang F (2000). The impact of the new economic model on latin americas agriculture. World Dev. 28:16731688.

Diederen $P$ (2003). Modernisation in agriculture: what makes a farmer adopt an innovation? Int. J. Agric. Resour. 2:328-342.

Figueiredo NMS, Hoffmann RA (1998). Dinâmica da modernização da agricultura em 299 microrregiões homogêneas do Brasil: 1975, 1980 e 1985. In: XXXVI Congresso Brasileiro de Economia e Sociologia Rural. Poço de Caldas, Anais. pp. 439-450.

Gardner BL (2001). Agriculture, Economics of International Encyclopedia of the Social and Behavioral Sciences. 32:337-344.

Gollin D (2010). Agricultural Productivity and Economic Growth. Handb. Agric. Econ. 4:2825-2866. 
Hair JF, Tatham RL, Anderson RE, Black W (1998). Multivariate Data Analysis. $5^{\text {th }}$ Ed. New York: Prentice Hall.

Hartman HH (1976). Modern factor analysis. Chicago: The University of Chicago Press, $3^{\text {rd }}$ Ed.

Hoffmann R (1992). A dinâmica da modernização da agricultura de em 157 microrregiões homogêneas do Brasil, Revista de Economia e Sociologia Rural 30(4):271-290.

Instituto Brasileiro de Geografia e Estatística - IBGE (2006). Censo Agropecuário de 2006 - Pará. Rio de Janeiro.

Instituto Brasileiro de Geografia e Estatística - IBGE (2008). Produção Agrícola Municipal. Rio de Janeiro.

Jin M, Yun H, Jeong CS, Heo JH (2011). Factor analysis and multiple regression between topography and precipitation on Jeju Island, Korea. J. de Hydrol. 410:189-203.

Johnston BF, Mellor JW (1972). El papel de la agricultura en el desarrollo económico. IN: Desarrollo Agricola, Flores, E. Mexico: Fundo de Cultura.

Kageyama A, Buainain A, Reydon B, Graziano J, Silveira JM, Fonseca M, Ramos P, Fonseca R, Belik W (1990). O novo padrão agrícola brasileiro: do complexo rural aos complexos agroindustriais. IN: Agricultura e Políticas Públicas. Delagado G, Gasques JG, Villaverde CM (Coord.). Brasília DF: IPEA, Série IPEA, P. 127.

Mardia K, Kent J, Ibby J (1980). Multivariate Analysis. New York: Academic Press.

Pastore J (1973). Agricultura e desenvolvimento. Rio de Janeiro: APEC/ABCAR.

Nurske R (1957). Problemas de formação de capital em países subdesenvolvidos. Rio de Janeiro: Editora Civilização Brasileira.
Pena HWA, Costa R, Bahia PQA (2008). Dinamic of exportation in Para state between 2004 and 2005. Facientifica 1:126-142.

Pison G, Rousesseeeuw PJ, Filzmoser P, Croux C (2003). Robust facto analysis. J. Multivar. Anal. 84:145-172.

Rodrigues A, Paulo E (2009). Introduction to multivariate analysis. In: CORRAR, L. J; PAULO, E; FILHO, J. M. D (Eds.). Multivariate analysis to administration and economy courses. São Paulo: Atlas, pp. 1-72.

Santana AC de (2002). Impactos socioeconômicos do FNO nas atividades produtivas da Região Norte: análise de insumo-produto. IN: O Fundo Constitucional de Financiamento do Norte e o Desenvolvimento da Amazônia, Santana AC de. Belém: M\&S Editora.

Souza RF, Khan AS (2001). Modernização da agricultura e hierarquização dos municípios maranhenses. Revista de Economia e Sociologia Rural, Brasília 39(2):81-104. 